\title{
Impact of Macro Economy on Financial Stability in Malaysia
}

\author{
Bambang Hadi Prabowo \\ (STIE Jaya Negara Taman Siswa Malang) \\ Maria Garcia \\ (European School of Economics)
}

\begin{abstract}
Research studies the influence of macroeconomic factors (inflation, exchange rates, and interest rates) and bank-specific factors (credit) on Non-Performing Loans (NPLs) in Malaysia for the period 2015 to 2018. This study uses the Vector Error Correction Model (VECM) to determine the effect of variables. independent consisting of macroeconomic factors and bank-specific factors. Based on the VECM estimation results, three variables that have a positive and significant effect on long-term NPL are credit, inflation and interest rates. Meanwhile, in the short term, there are only two variables that have a positive and significant effect on NPL, namely credit and interest rates. Inflation and exchange rate variables have a negative and insignificant effect on NPL in the short term.
\end{abstract}

Keywords: Rural Banks, Macroeconomic Indicators, NPLs, Financial System Stability, VECM

\section{Background}

Several factors that affect financial system stability, in theory, are capital flows, exchange rates, interest rates, inflation, the ratio of non-performing loans (Non-Performing Loans), and others. The ratio of non-performing loans (NPL) to total credit, commonly known as the ratio of NPL to total credit, is the ratio between the number of loans classified as substandard, doubtful, and non-performing, to total credit (Lehner, 2016). In line with the increase in the amount of credit to microfinance institutions, there are indications that financial risk will also increase. Thus, it turns out that this increase is still not effective in resolving economic problems, especially its effect on financial system stability, so this study was conducted to determine the level of financial risk in Malaysia and the effect of credit from microfinance institutions, as well as the influence of several macroeconomic variables, namely inflation, interest rates, and value exchange rate against credit risk (NPL). Macroeconomic variables are taken because macroeconomic indicators can affect bank liquidity so that they become one of the determining factors for the level of bad credit (Cornock, 2018).

Macroprudential and macroprudential can act as indicators of financial system stability (Dombret \& Lucius, 2013). Macroprudential indicators include capital flows, exchange rates, interest rates, and the ratio of bad loans. Meanwhile, according to Akerlof's 1970 research in Ramlall (2018), financial system stability rests on three pillars, namely information asymmetry, adverse selection, and moral hazard. The three pillars are traditional factors that cause bad credit. The existing theoretical gaps are caused by differences in the assumptions used in the study. 


\section{Literature review}

Microfinance is a financial service for low-income groups of people that includes credit, savings, installment, payment, and money transfer services. In general, microfinance services are aimed at low-income groups of people (Schmidt, et al., 2016).

Microfinance institutions help low-income people access financial services. Where low-income people generally cannot access banking services. Microfinance institutions generally operate with easier and simpler terms than services provided by banks because they are intended for people who have not been able to access banking services, small companies, or micro-companies that do not have banking access or cannot access banking services are also included in the target. microfinance services that aim to help micro enterprises develop and succeed in managing and developing their businesses through microfinance services. Micro companies certainly need capital services. However, because banks have not been able to serve micro-businesses, microfinance services have become an alternative financial service that can help micro businesses to obtain capital services and other financial services.

According to Keynes in Cammarosano (2016), he explains that money is a form of wealth that a person has. In this study, the authors emphasize the speculative motive as a derivative of Keynes' grand theory of money demand. Keynes differs from the classics in his emphasis on speculative motives and the role of the interest rate in determining the demand for money for speculative purposes.

The theory of bank behavior is a derivative of Keynes's theory of money demand. The theory of bank behavior states that human interactions determine the interest rate in banks. Public behavior in using banking products can cause banks to become more or less liquid so that every banking product offered has risks. This risk will be detrimental to all aspects involved. Moreover, it will disrupt financial system stability. The theory of bank behavior is a derivative of Keynes' money demand theory with speculative motives (Fontana \& Setterfield, 2016).

An increase in interest rates will worsen the quality of the loan, the higher the cost of debt, the more difficult it will be for debtors to repay the loan. In addition, high-interest rates are an alternative that has the potential to harm debtors (Bofondi, et al., 2011).

Inflation is a macroeconomic factor that affects the efficiency of banking activities. Inflation lowers the value of money, which reduces the general rate of return. The decline in capital investment has a negative impact on economic performance. The inflation rate is an indicator that is often used to measure the stability of the prices of goods and services. Inflation is defined as a continuous increase in the general price level over a certain period.

According to Mankiw (2013), currency exchange rates are the exchange rates of currencies against other currencies in international trade. NPL theory related to bank stability rests on three pillars: (i) information asymmetry, (ii) adverse selection, and (iii) ) moral hazard theory. The theory mentions the traditional causes of bad credit loans which translate into banking system instability (Scardovi, 2015).

The definition of credit is the provision of money or an equivalent bill, based on a loan agreement or agreement between the lender and the borrower, which requires the borrower to pay off his debt after a certain period of time with interest (Green, 2016). According to several types of literature, excessive 
credit growth is often associated as a key factor causing crises in the financial sector, particularly in developing countries. The major banking crisis in the last 30 years that occurred in Chile in 1982 (Oberfield, 2013), Denmark, Finland, Norway, and Sweden was called The Nordic Banking Crisis occurred in the early 1990s (Schweiger, 2014), the Mexican crisis in 1994 ( Sosa \& Ortiz, 2015), the Asian financial crisis in 1997 (Joe \& Oh, 2018) and the Rakyatime mortgage credit crisis in the United States that occurred in 2008 (Flavin \& Sheenan, 2015) and the European debt crisis that occurred in 2010 - 2013 (Keddad \& Schalck, 2020) also began with a credit boom period.

\section{Research methods}

Based on the research objectives, namely to determine the effect of bank-specific factors (credit) for Rural Banks and macroeconomic variables (inflation, interest rates, exchange rates) on Non-Performing Loans without ensuring the existence of cause and effect in Malaysia, the type of data used in this study is secondary data in the form of time series data with the period 2015 January to 2018 in December with all Rural Banks in Malaysia as objects.

Then the data is analyzed to determine the effect between variables using the Vector Error Correction Model (VECM). This type of research is a type of quantitative research because this study aims to find results in the form of data in the form of numbers which are used as a means of analyzing information about what you want to know.

The model specification used is the VAR method adopted from the research of Sigh and Sudana (2017). Sigh and Sudana (2017) in their research include the variable Non-Performing Loan (NPL), credit, bank size, ROA, IRL, and CAR as proxies of bank-specific factors. And using the variables GDP, exchange rates, inflation, and interest rates as proxies of macroeconomic variables. Sigh and Sudana (2017) consider that this model can explore the relationship between direct aspects and models that are relevant for the analysis of the effect of macroeconomic variables and bank-specific factors on Non-Performing Loans (NPL).

The models used in Sigh and Sudana (2017) are as follows:

$$
N P L=\beta_{0}+\beta_{1} G D P_{1}+\beta_{2} I N F_{2}+\beta_{3} E X_{3}+\beta_{4} \text { Bank Size }_{4}+\beta_{5} R O A_{5}+\beta_{6} C A R_{6}+\beta_{7} I R L_{7}+\mu i
$$

Specifically, the above equation is formed in the econometric model as follows:

$$
N P L=\beta_{0}+\beta_{1} C D R_{1}+\beta_{2} I N F_{2}+\beta_{3} N T R_{3}+\beta_{3} S B A_{4}+\mu i
$$

Where:

NPL $=$ Non Performing Loan

CDR1 $=$ Credit growth of microfinance institutions

INF2 = Inflation rate

NTR3 = Exchange rate

SBA4 = Interest rate

ui $=$ Error rate

$\beta 0=$ Parameter constant / Intercept

$\beta 1, \beta 2, \beta 3,=$ The coefficient of the independent variable is $x 1, x 2, x 3$ 


\section{Results and Discussion}

The unit root test results as shown in the table below show that all the variables to be estimated are: NPL, credit, inflation, exchange rates, and interest rates are not stationary. Whereas in the unit root test at the first different level, all the variables to be estimated do not contain unit roots so they are stationary. Following are the results of the stationarity test:

Table 1: Stationarity Test Results

\begin{tabular}{|l|l|l|l|l|}
\hline \multirow{2}{*}{} & \multicolumn{3}{|l|}{ Level } & First Different \\
\cline { 2 - 5 } & Probability & Caption & Probability & Caption \\
\hline NPL & 0.2432 & not stationary & 0.0000 & stationary \\
\hline CDR & 0.7136 & not stationary & 0.0000 & stationary \\
\hline INF & 0.0000 & stationary & 0.0000 & stationary \\
\hline NTR & 0.2441 & not stationary & 0.0000 & stationary \\
\hline SBA & 0.0010 & stationary & 0.0000 & stationary \\
\hline
\end{tabular}

\section{Optimal Lag Test}

The selection of lag four as the optimal lag in this study is based on the use of the minimum Akaike Information Criteria (AIC) value of the variables estimated in the equation, namely Non Performing Loans (NPL), credit, inflation, exchange rates. and interest rates. The fourth lag was chosen because it produced a minimum Akaike Information Criteria (AIC) value, meaning that the model was able to explain the relationship between variables in this study.

Table 2: Optimal Lag Test Results

\begin{tabular}{|l|l|l|l|}
\hline Lag & LR & FRE & AIC \\
\hline 0 & NA & $1.99 \mathrm{E}+10$ & 36.8121 \\
\hline 1 & 312.4715 & 13314138 & 30.3215 \\
\hline 2 & 28.75294 & 15512162 & 30.6531 \\
\hline 3 & 41.7045 & 12231412 & 30.3214 \\
\hline 4 & 43.06198 & 8094131 & $\mathbf{2 9 . 6 7 4 3 *}$ \\
\hline
\end{tabular}

\section{VAR Stability Test}

VAR modeling is declared stable if in determining the optimum lag, all variables have a Modulus Roots of Characteristic Polynomial value that is smaller than one (Levendis, 2019). If the VAR system is unstable, the results obtained, such as IRF and VD, are invalid. After testing the stability of the VAR, the VECM can be estimated. In this study, the VAR model is stable; that is, the average modulus value of the variable is 0.896584 , which is less than 1 .

\section{Cointegration Test}

The results of the Johansen Cointegration Test show that the Trace Statistic value has a greater value than the Critical Value. So based on these four equations, the Vector Error Correction Model (VECM) model can be used in this study. 
Table 3: Cointegration Test Results

\begin{tabular}{|l|l|l|l|l|}
\hline & Eigenvalue & Trace Statistic & 0,05 Critical Value & Probability \\
\hline None* & 0.759435 & 149.5263 & 69.81899 & 0.0000 \\
\hline At most $1^{*}$ & 0.580723 & 88.26137 & 47.8561 & 0.0000 \\
\hline At most $2^{*}$ & 0.529874 & 50.8847 & 29.7971 & 0.0001 \\
\hline At most $3^{*}$ & 0.347615 & 18.43027 & 15.4947 & 0.0175 \\
\hline
\end{tabular}

Information: $5 \%$ probability

\section{Granger Causality Test}

The test results indicate that credit causes NPL and vice versa NPL causes credit. Followed by interest rates cause inflation and vice versa inflation causes interest rates. Then the interest rate causes credit and credit to also generate interest rates because these variables have a probability value that is smaller than the Critical Value of 5\% so that it is stated to have a causal relationship.

Table 4: Granger Causality Test Results

\begin{tabular}{|l|l|l|l|l|}
\hline NPL & Credit & Inflation & Exchange rate & Interest Rates \\
\hline- & $0.0321^{*}$ & $0.0517 * *$ & $0.1597 * *$ & $0.7711^{* *}$ \\
\hline $0.3324^{* *}$ & - & $0.6226^{* *}$ & $0.5870^{* *}$ & $0.0010^{*}$ \\
\hline $0.0215^{*}$ & $0.6018^{* *}$ & - & $0.8444^{* *}$ & $0.3304^{* *}$ \\
\hline $0.9287^{* *}$ & $0.6841^{* *}$ & $0.6247 * *$ & - & $0.0885^{* *}$ \\
\hline $0.2772 * *$ & $0.0341^{*}$ & $0.7206^{* *}$ & $0.5135^{* *}$ & - \\
\hline
\end{tabular}

Information: $5 \%$ probability

Note: * (has a causality relationship), ** (does not have a causality relationship)

Table 5 : Short Term VECM Estimation Results

\begin{tabular}{|l|l|l|}
\hline Variable & Coefficient & \multicolumn{2}{l|}{ T-statistics } \\
\hline Long-term & 0,00011 & $-4,70396$ \\
\hline D(CDR(-1)) & 0,39959 & $-5,93812$ \\
\hline D(INF(-1)) & 0,00026 & $-0,05960$ \\
\hline D(NTR(-1)) & 0,16596 & $-0,240687$ \\
\hline D(SBA(-1)) & $-0,048474$ & \\
\hline C & 0,20325 & \\
\hline Short-term & 0,19307 & $-4,36820$ \\
\hline CointEq1 & 0,24322 & $-2,05044$ \\
\hline D(NPL(-1),2)) & 0,00017 & $-3,22031$ \\
\hline D(NPL(-2),2)) & $8,2 \mathrm{E}-05$ & 0,99419 \\
\hline D(CDR(-1),2)) & 0,32772 & 1,21928 \\
\hline D(CDR(-2),2)) & 0,38153 & $-4,99535$ \\
\hline D(INF(-1),2)) & 0,00013 & $-5,57208$ \\
\hline D(INF(-2),2)) & 0,00019 & $-0,76731$ \\
\hline D(NTR(-1),2)) & 0,07707 & $-0,47660$ \\
\hline D(NTR(-2),2)) & 0,09106 & $-4,31502$ \\
\hline D(SBA(-1),2) & 0,03106 & $-1,15329$ \\
\hline D(SBA(-2),2)) & & $-1,38357$ \\
\hline C &
\end{tabular}

In the short term, the credit variable has a significant effect on NPL. This result causes the credit growth of the People's Credit Bank to increase in the short term so that the NPL, which is an indicator of financial system stability, will increase. This means that the higher the NPL, the instability of the financial system or in other words, the financial system stability will be disrupted. The short-term variable inflation does not have a significant effect on the NPL level. This is known by looking at the T-statistics value of the inflation variable below the T-table value. This means that if there is an increase in the inflation rate in the short term it will not affect the NPL level. Another macroeconomic 
variable that does not affect the NPL rate is the exchange rate. In this study, the interest rate variable affects the NPL level. This happens because if the interest rate is raised, the debtor will not be able to pay the installments that he borrowed, causing the NPL level to increase.

In this study, the regression test results state that there is a relationship between variable credit and variable NPL. In the long run, there is a relationship between inflation and NPL. Inflation and NPLs have a significant positive relationship in the long run. Inflation and NPL have a significant positive relationship in the long term of 0.39959 . This means that if there is an increase in the exchange rate by one percent, in the long term the NPL will increase by 0.39959 percent. There is a positive relationship between interest rates and NPLs. Then, in the long run, the increase in the exchange rate does not have a significant effect on NPL.

In this study, it can be seen that exchange rate fluctuations are inversely proportional to the NPL level from 2015 to 2018. This is because other NPL variables such as credit, inflation, and interest rates in Malaysia have increased.

In this study, in the 2015 to 2018 period, there were various kinds of economic turmoil which caused credit figures, inflation, exchange rates and interest rates for non-performing loans (NPLs) to fluctuate. So far, there have been at least a number of macroeconomic symptoms affecting the Malaysian economy which can directly affect the banking sector, especially Rural Banks. Several monetary events that occurred in the 2015-1 to 2018-12 period were financial pressures and global political uncertainty related to the global economy. Based on this study, where macroeconomic indicators are measured using inflation, exchange rates, and interest rates, specific factors for rural banks are measured using credit growth, and NPL shows that there is a good long-term and short-term relationship.

Credit variable as an indicator of bank-specific factors which in this study is more devoted to microcredit, namely Rural Banks throughout Malaysia have a significant positive effect on NPL of Rural Banks . An increase in credit caused by public consumption, an increase in public income, or for the productive sector in micro-business development raises the risk of an increase in the level of NPL (bad credit) which will disrupt the stability of the financial system in Malaysia. the banking sector itself. The high credit growth of Rural Banks was also accompanied by high quality, where the NPL ratio was able to be maintained up to $0.3 \%$. According to Financial Authority, this crisis did not really disrupt credit growth; However, credit at rural banks, rural banks, and conventional banks is experiencing a slowdown.

\section{Conclusion}

Test results for macroeconomic variables and bank specific factors for Non-Performing Loans (NPL) in Malaysia using VECM. Provides results that the NPL Variable provides a positive and significant response to credit increases in the short and long term. This means that high and low credit levels lead to high and low NPL levels.

The inflation variable used as a macroeconomic indicator has different effects on the level of NPL in the short and long term. In the short run, variable inflation is detrimental to the NPL level. This means that the increase in the inflation rate does not affect the NPL level. Meanwhile, in the long term, inflation has a positive and significant effect on the NPL level. That is, an increase in the inflation rate increases the NPL level. Inflation that increases this increase is caused by government 
policies to increase the price of goods which causes prices to also rise. Then this can affect people's purchasing power so that the business world weakens. Resulting in hampered credit.

The next macroeconomic variable is the exchange rate variable. The exchange rate has a negative and insignificant effect on NPL in the long and short term. This means that depreciation or exchange rate appreciation does not affect credit payments provided by Rural Banks / Non-Performing Credit Rates (NPLs) in the long or short term.

Interest rate variable has a positive and significant effect on the NPL level. This means that an increase in interest rates will also increase the level of long-term and short-term non-performing loans (NPL) in Malaysia.

\section{Reference}

Bofondi, Marcello dan Ropele, Tiziano. (2011). Macroeconomic Determinants of Bad Loan: Evidence from Italian Bank. Questional Papers Economia e Finanza

Bekhet, H. A., \& Matar, A. A. (2012). Causality of Macroeconomic Variables. Conference on Asian Forum on Business Education.

Cammarosano,J.R. (2016).A Wider View of John Maynard Keynes: Beyond the General Theory of Employment.Lanham : Lexington Books

Cornock,O.(2018).The Report: Malaysia 2018.Oxford : Oxford Business Group

Dombret,A.R., Lucius,O.(2013).Stability of the Financial System: Illusion Or Feasible Concept?. Cheltenham : Edward Elgar

Fontana,G., Setterfield,M.(2016).Macroeconomic Theory and Macroeconomic Pedagogy. Cham : Springer

Flavin,T.J., Sheenan,L.(2015).The role of U.S. subprime mortgage-backed assets in propagating the crisis: Contagion or interdependence?.The North American Journal of Economics and Finance.Volume 34, November 2015, Pages 167-186.DOI :https://doi.org/10.1016/j.najef.2015.09.001

Green,R.(2016).Classical Theories of Money, Output and Inflation.Cham : Springer

Joe,D.Y., Oh,F.D.(2018).Credit ratings and corporate cash holdings: Evidence from Korea's corporate reform after the 1997 Asian financial crisis.Japan and the World Economy.Volume 45, March 2018, Pages 9-18.DOI :https://doi.org/10.1016/j.japwor.2017.11.003

Keddad,B., Schalck,C. (2020).Evaluating sovereign risk spillovers on domestic banks during the European debt crisis.Economic Modelling.Volume 88, June 2020, Pages 356-375. DOI :https://doi.org/10.1016/j.econmod.2019.09.047

Lehner,O.M. (2016) .Routledge Handbook of Social and Sustainable Finance.London,UK : Routledge Levendis,J.D. (2019).Time Series Econometrics: Learning Through Replication.Cham,switzerland : Springer 
Linda, M. R., Megawati, \& Deflinawati. (2015). Pengaruh Inflasi, Kurs Dan Tingkat Suku Bunga Terhadap Non Performing Loan Pada PT. Bank Tabungan Negara (Persero) Tbk Cabang Padang. Journal of Economic Education, 137-144.

Mankiw, N. G. (2013). Principle of macroeconomics Singapore: Cengate

Oberfield,E.(2013).Productivity and misallocation during a crisis: Evidence from the Chilean crisis of 1982.Review of Economic Dynamics. Volume 16, Issue 1, January 2013, Pages 100-119. DOI :https://doi.org/10.1016/j.red.2012.10.005

Ramlall,I. (2018).Understanding Financial Stability.Bingley : Emerald

Scardovi,C.(2015).Holistic Active Management of Non-Performing Loans. Cham : Springer

Schmidt,R.h., Seibel,H. D., Thomes,P.(2016).From Microfinance to Inclusive Finance: Why Local Banking Works. Hoboken : John Willey and Sons Pristina. 2017. Macroeconomic and Bank-Specific Determinants Of Non-Performing Loan in Macedonian Banking System-Panel Data Analysis. Journal of Central Bank of the Republik of Kosovo (Head of Financial Stability Unit)

Schweiger,C.(2014). The EU and the Global Financial Crisis.Cheltenham : Edward Elgar

Sosa,M., Ortiz,E.(2015).Desequilibrios cambiarios y crisis: Canadá, México, Japón y Reino Unido vs dólar de EE.UU. (1994-2014)Exchange rate disequilibria integration and crisis: Canada, México, Japan and United Kingdom vs EE.UU. dollar (1994-2014).Contaduría y Administración.Volume 60, Supplement 2, October-December $\quad 2015, \quad$ Pages 106-127. DOI :https://doi.org/10.1016/j.cya.2015.08.014

Sudana, S.K Sigh. (2017). Determinants of Non-Performing Loan Comparativa Study of Bank in Malaysia dan Nepal. Increasing Management Relevance and Competitiveness. CPD Certified, Surabaya : Universitas Airlangga 